\title{
An Equal Opportunity Practice in Education: Determination of Classes by Draft in Schools
}

\author{
Suzan Canlı,", Mete Kızlkaya², Necmettin Beyaz² \\ ${ }^{1}$ Department of Educational Administration, Faculty of Education, Niğde Ömer Halisdemir University, Turkey \\ ${ }^{2}$ Ministry of National Education, Turkey
}

Copyright $(2019$ by authors, all rights reserved. Authors agree that this article remains permanently open access under the terms of the Creative Commons Attribution License 4.0 International License

\begin{abstract}
The aim of the present study was to assess the implementation of "the draft-based branch determination" in Adiyaman provincial center primary and middle schools in Turkey based on the views of the school stakeholders. The study was conducted with the mixed method and the total number of participants in the qualitative section of the study was 72 and the total number of participants in the quantitative section was 1128. In the study, the qualitative data were collected with a semi-structured interview form, and the quantitative data were collected with the "Draft-based branch determination application assessment survey." The qualitative study data were analyzed with descriptive and content analysis, while quantitative data were analyzed with descriptive statistical analysis and chi-square test. In the qualitative section of the study, half of the participants stated the negative aspects of this practice, while 6 did not provide any opinion on the negative aspects of the practice and 25 participants stated that the practice had no negative aspects. On the other hand, 71 participants expressed views on the positive aspects of the practice. In the quantitative section, the participants participated in the positive statements about the practice at a higher rate when compared to the negative statements. The majority of the participants desired the practice to prevail in the future. While there was a significant correlation between the views on the maintenance of the draft-based branch determination system and the stakeholder variable, there was no significant correlation with the school type variable. In conclusion, it can be suggested that the qualitative study findings were consistent with the quantitative findings and the qualitative findings could be generalized for a larger sample group.
\end{abstract}

Keywords Equality of Opportunity in Education, Draft-based Branch Determination, School Administrator, Teacher, Parent

\section{Introduction}

One of the most important factors on national social and economic development is education and the countries with a high level of education system are more successful in development. In addition to the high level of education, another important factor is providing equal educational opportunities to all social classes [1], since education is one of the basic individual rights. The violation of the individuals' right to education undermines the development of democracy, social progress, international peace and security. Thus, states should be responsible of education and instruction and ensure that all individuals receive a qualified education with equal opportunities. This is a prerequisite of the social state [2].

Today, the equality of individuals in education is guaranteed by law in most countries. However, this does not suggest that equality of opportunity in education is fully achieved. Although there are no legal obstacles, it was observed that individuals cannot benefit from educational opportunities equally. It is for this reason that it is not sufficient to justify the equality of opportunity in education by law, and it is important to establish the necessary conditions for that to actually happen [3]. Since it is difficult to argue that educational reforms could be successful in an inequal society [4], a decrease in the quality of education would be inevitable.

Although there are studies on equality in education in the literature based on race, gender, socioeconomic level, residential status and regional groups [1,3,5-12], factors such as individual's mental abilities, disability, language, religion, physical equipment in schools, and teacher qualifications are only some of the factors that may lead to educational inequalities. Conditions such as girls' access to education, the high impact of socioeconomic status on educational opportunities, its impact on academic achievements, inability to complete education due to dropouts, impossibility for all individuals to acquire basic educational skills, the inadequate access to preschool education are the examples for inequality of opportunity 
in education [4]. In this context, it could be suggested that equality in education has two dimensions of justice and inclusivity. The justice dimension is the lack of obstacles to individual educational potential due to personal and social attributes such as gender, ethnicity and socioeconomic status. Inclusivity is the provision of a basic standard of minimum education such as acquisition of reading, writing and basic academic skills by all [13].

According to 2016 statistics, while the rate of illiterate women in 6 and above years of age was $5.9 \%$, the rate of illiteracy among men was $1.1 \%$ in Turkey [36]. According to this, in terms of gender inequality in education, it can be suggested that girls are more disadvantaged than boys. When families have both girls and boys, they want boys to benefit more from educational opportunities and that they give priority to boys [9]. In fact, a negative relationship between the number of daughters owned by families and school enrollment was determined more than the number of sons [29]. In order to resolve the inequality of opportunity in education in terms of gender, such projects and campaigns were carried out in Turkey as "Let's Go to School, Girls!", "Daddy Send Me to School", "Snowdrops-the Girls of Modern Turkey", "Mothers and Daughters Together at School", "Girls' Schooling Support Campaign", "Support to Education by 100\%", "Support to Basic Education" [14,15].

One of the factors that hinder the equality of opportunity in education is the economic factors, so that children coming from families with low socioeconomic income are more disadvantaged, affecting the amount and type of education they take [34,35]. While families with good income can provide their children with additional educational facilities such as private tutoring and the necessary school equipment, the children of families with poor income are experiencing problems in providing these facilities. Thus, this leads to inequality of opportunity in terms of academic success in education, confirming the findings of the research literature. For example, Yaşar [12] found that students who received additional education facilities such as private tutoring were more successful in central system assessments such as "Examination for transition to high school" and "Examination for transition to higher education" than those who did not, indicating that there was a significant difference between the children of families with the lowest and highest income levels in favor of the families with the highest income. To eliminate disparities in terms of socioeconomic conditions in Turkey, such applications as conditional cash transfer, free distribution of textbooks, in-kind and cash assistance to families with low economic income, and private tutoring support to children have been carried out so far.

Also, there is evidence supporting the inequality in education in terms of geographical and urban-rural conditions. For instance, according to Buluç [5], there are quite big differences in the rate of schooling between regions and urban-rural conditions. According to Gürel and Kartal [7], while the number of students per school in all levels of education is highest in the province of Istanbul, it is below the average of Turkey in Northeastern Anatolia, East of Black Sea, and West of Marmara regions. In terms of schooling rate, the lowest rate in primary school level is in Çankırı, Tokat, and Gümüşhane provinces; the highest enrollment rate is in Zonguldak, Artvin, and Samsun provinces. Besides, academic proficiency levels vary by region and students at the lowest levels in Turkey are living in the eastern region of the country [37]. According to Yaşar [12], there is a significant difference in terms of being successful at "Examination for transition on higher education", between the students living in urban and rural areas, in favor of students living in urban areas. Referring to the reason for this situation, İçer [1997, as cited in 2] stated that the lack of schooling, teachers, and school equipment in rural settings affect the inequality of opportunity in education are due to inbalancing the educational opportunities between regions as well as urban-rural settlements. For the elimination of inequality in terms of geographical and urban-village conditions in Turkey, boarding schools have been opened, and students were provided with food, drink, textbooks, and pocketmoney via these schools [4]. In addition, the transportation of students to school have been provided by the mobile primary education, and the equality has been tried to be established in terms of the technological structure in the schools with the help of Fatih Project that was designed to provide each student with the highest quality educational content and to ensure equal opportunities in education [38].

Furthermore, to achieve equality in educational opportunities, applications such as increasing the number of schools, decreasing the class size, introduction of elective native language courses, increasing the number of laboratories at schools and religious education schools, extending the compulsory education to 12 years, improving schooling in preschool education, increasing the number of universities, abolishing tuition in universities, increasing grants and other sponsorship facilities, education and rehabilitation of students with disabilities [16], inclusive education, incentives for support services at schools, organization of physical conditions for disabled individuals at schools, and practices to increase employment in the eastern regions of the country were conducted. However, it could be argued that these qualitative and quantitative measures failed to ensure the equality of opportunity in education $[4,17]$.

According to Tansel [18], inequality of opportunity in education constitutes the majority of the inequality in academic achievement in Turkey. Although there has been a decrease in the inequality of opportunity in education in time, it was determined that the domestic variables (such as the level of education of the parents) play an important role in the inequality in academic achievement. On the other hand, according to Polat [4], the differences between 
the achievements of students in Turkey were largely due to the differences in quality between the schools and socio-economic conditions.

Differences in quality between the schools may affect the demand for these schools. Parents, who desire a quality education for their children and are sensitive to this issue and with an adequate socioeconomic status, enroll their children in schools they perceive as high quality schools. This leads to preference of particular schools, which is defined as the preference of parents to decide the school their children would attend. Although the choice of school is common in higher education and secondary education, it has been debated in basic education. In recent years, the scope of school choice was expanded to middle schools in certain countries. This was partly due to the increased demand of parents to choose, and partly it was considered as a means of promoting better performance. This is considered as an advantage for students with higher-educated parents, while it could be a disadvantage for those with parents with lower education, since parents with a higher level of education could make choices with more awareness. Furthermore, school selection may lead to additional costs such as uniforms, transportation, textbooks, and voluntary financial payments, even though there are no enrollment fees at schools [13]. On the other hand, in high-demand schools, an illegal enrollment fee is charged under the disguise of voluntary donations $[4,19]$.

The countries with high level of school choice tend to have socially segregated school systems [13]. The socio-economic segregation of schools is a significant problem in several countries and measures are implemented in certain countries. For example, while there are socioeconomic differences of schools in countries as Hungary, Turkey, Mexico, Belgium, Slovakia, and Austria, such differences are very few in schools of countries as Sweden, Finland, and Norway. [13]. To prevent school selection, address-based enrollment system was initiated in Turkey. Thus, high demand for some schools and transportation costs have decreased considerably. In order for this system to function well, it is necessary to develop equal education opportunities in all schools and to control the system efficiently [4]. However, certain problems are experienced in address-based enrollment system. One of the reasons for these problems is the fake address changes made by the parents. Parents use this method to enroll their children in the schools they desire or where the teachers that they prefer to educate their children are employed [19]. The socioeconomic segregation of the schools is inevitable as long as these types of problems prevail [4].

Quality and socioeconomic differences between the schools could lead to differences between student achievements. Differences in student achievement could occur between schools due to the resources and the climate of the school. A school with a strong academic climate positively affects student motivation and achievement. However, there are also differences between the student achievements in the same school. The differences between the achievements of the students with same skills and domestic resources suggest that unequal opportunities are provided to students at school. Thus, the differences between the achievements of the students attending the same school could be due to the inability to access the resources equally [20]. Presence of classes with different achievement levels in the same school, the qualifications of teachers, the teaching methods implemented, the course material, the classroom climate, peer interactions, the socioeconomic status of the classroom and the homogeneity of student achievements, etc. could be the cause of the differences of student achievement. The research literature reports that the class size, school size, teacher qualifications and other school-related variables are considered as important factors that affect learning [21].

\subsection{The Significance and Aim of the Study}

In Turkey, students are enrolled at the closest school to their registered home address due to the address-based enrollment system. However, certain parents unlawfully change their registered address to enroll their children at the school of their choice, especially at schools where the teachers they prefer are employed [19]. Thus, they can enroll their children to the school of their choice, rather than to the school in their settlement address. Furthermore, they could also use their economic power to enroll their children in the branch where the teacher they prefer would instruct the students. In fact, the fact that high-demand schools charge an illegal enrollment fee under the disguise of voluntary donation demonstrates this phenomenon $[4,19]$. In other words, when parents want to place their children in the classrooms where teachers, who are considered to be more qualified and relevant, are serving the teaching profession, the school principal places these children in these classrooms for a certain fee (illegal, determined by school principals, varies school to school or principal to principal). As a result, students are piled in certain schools and in the classrooms of certain teachers and selected branches are assigned to teachers, who were demanded by parents and the remaining students are enrolled in other branches. This could lead to differences between student achievement, as well as considering the student in certain branches as successful or unsuccessful. The difference between student achievements could derive from personal skills, domestic variables, school facilities, and the influence of their peers and teachers; however, it is the teacher factor causes the highest difference besides the personal skills [22]. The teacher factor is important in academic achievement $(21,23]$, and there is a strong correlation between student achievement and teacher quality [24]. Therefore, the quality of the education 
offered to the students by the teacher in the classroom and student-teacher interaction are important for the quality of the education offered to individuals [25]. Based on the above-mentioned factors, it can be suggested that there is an inequality of opportunity among the students attending the same school. Since equality of opportunity in education includes the equal access of students to all educational services without any discrimination [4], all individuals in a society should have the same and adequate access to educational services to improve their skills [3].

In order to prevent the inequality among the students attending the same school due to the reasons mentioned above, the classrooms of the students were determined with a draft-based assignment system in Adiyaman province, Turkey. In this application, the branches of the students who would start 1 st grade in the primary school and the 5th grade in middle school, and the teachers of the $1^{\text {st }}$ grade students were determined by a lottery in the address-based enrollment system. In order to equally distribute the female and male students in the branches, the names of the female and male students were drawn separately. After the branches of the $1^{\text {st }}$ grade students were determined, the teachers that would teach these branches were also drafted. In middle schools, only the branches of the $5^{\text {th }}$ grade students were determined by draft and the teacher names were not drawn. It was considered that the application would prevent teacher selection and formation of elite classrooms in schools, as well as prevention of school selection and effective operation of the address-based enrollment system. The practice was considered significant with its possible contribution to the literature and future educational policies since it was assessed based on the views of school stakeholders and its advantages and disadvantages were determined and it was considered that the application could contribute to equality of opportunity in education. Thus, the aim of the present study was to evaluate the implementation of "draft-based branch determination" in primary and middle schools in the 2017-2018 academic year based on the views of school stakeholders (school administrators, teachers and parents). For this purpose, the following research problems were identified:

1. What are the views of the participants on the advantages and disadvantages of the determination of branches by draft?

2. What are the perceptions of the participants on the assessment of draft-based branch determination application?

3. Is there a significant difference between the views of the participants on sustenance of the draft-based branch determination application based on stakeholder variable?

4. Is there a significant difference between the views of the participants on sustenance of the draft-based branch determination application based on school type variable?

\section{Method}

The present study is a case study conducted with descriptive survey model. The case study is also referred to as sample case study and it is a distinctive approach used to search for answers to scientific questions [26]. Case studies could be conducted with qualitative or quantitative methods. Independent of the implemented method, the aim is to reveal the findings about a case [27]. Case studies are suitable to research a specific phenomenon such as a program, an institution, an individual, a process or a procedure in detail [28].

Exploratory mixed method was used in the study. The exploratory mixed method is a two-step sequential design, where initially the topic is explored qualitatively, an instrument is developed as a result of the qualitative research and quantitative research is conducted using this instrument. The primary objective in this method is to generalize the qualitative findings obtained with several participants to a larger sample via the quantitative research. In particular, this method is used in order to determine the significant forms when there is no specific measurement instrument, and the forms required to develop or test the measurement instrument are nor known. Furthermore, it is used in generalization of qualitative findings to different groups, to test the extent of a theory or classification, or to explore a phenomenon in depth and to measure its frequency [30]. In the present study, since there was no measurement instrument for draft-based branch determination application, initially, a qualitative study was conducted to design a "Assessment Survey for Draft-Based Branch Determination Application" and quantitative data were collected with this survey form to investigate whether the qualitative findings could be generalized to other groups.

\subsection{Population and Sample}

The study population included primary and middle school administrators, teachers instructing $1^{\text {st }}$ and $5^{\text {th }}$ grade classes and the parents of these students in Adiyaman province urban center in Turkey. Maximum diversity sampling method was used to determine the participants of the qualitative section of the study. In the qualitative section of the study, the school principal, 1 deputy principal from each school in Adiyaman urban center, 2 parents whose students attended 1st and 5th grades, and 3 teacher instructing the first and fifth grades (the teachers and parents of $1^{\text {st }}$ grade students in primary schools, the parents and teachers of the fifth grade students in middle schools) participated the study. The participants in the qualitative section of the study were 72 individuals, 21 of which were school administrators, 21 were parents, 30 were teachers, 22 were female, 50 were male, 36 participants were related to primary schools and 36 participants were related to middle schools. In the quantitative section of the study, an attempt was made to 
reach all school administrators and teachers, and parents who were accessible and volunteered to participate in the study were selected. The participants in the quantitative section of the study included 1128 individuals, of whom 123 were school administrators, 428 were parents, 577 were teachers; 465 were female, 663 were male, and 634 were related to primary schools and 494 were related to middle schools.

\subsection{Data Collection Instruments}

A semi-structured interview form was developed to collect qualitative data. In the interview form, questions on demographical information and two questions about the views of the participants on advantages and disadvantages of the draft-based branch assignment application were included. The quantitative data were collected with a 28 -item questionnaire developed using the answers given to the two questions included in the interview form used in the qualitative section. When developing the questionnaire, initially, 28 items were determined with the analysis of the qualitative data. Then, the questionnaire was sent to 4 field experts in Educational Administration and Supervision (4 Assoc. Prof.) and they were asked to determine whether the items were "adequate, should be removed, or reorganized" and they were asked to submit their recommendations, and 3 experts responded to the request. With the agreement of three researchers, the items requested to be omitted by at least one expert were excluded and the items requested to be reorganized were edited and the items requested to be added were included in the questionnaire if they were suitable for the aim of the study. Based on the above-mentioned evaluation criterion, 2 items were excluded from the questionnaire, 2 items were added, and 10 items were edited. Thus, the final questionnaire included 28 items. Each item included in the questionnaire was evaluated with a 5-point Likert scale: $1=\mathrm{I}$ completely disagree, $2=\mathrm{I}$ somewhat agree, $3=\mathrm{I}$ slightly agree, $4=\mathrm{I}$ mostly agree, $5=\mathrm{I}$ completely agree. The range of points for each point was (I) 1-1.80 I completely disagree, (II) 1.81-2.60 I somewhat agree, (III) 2.61-3.40 I slightly agree, (IV) 3.41-4.20 I mostly agree, (V) 4.215.00 I completely agree.

\subsection{Data Collection and Analysis}

The qualitative study data were collected between 30/04/2018 and 03/05/2018 with the interview form. The interview form was sent to schools by the Adiyaman Provincial Directorate of National Education and the directorate asked that the form should be completed by school principals, 1 deputy principal, 2 parents whose children were attending $1^{\text {st }}$ and $5^{\text {th }}$ grades and 3 teachers instructing $1^{\text {st }}$ and $5^{\text {th }}$ grades (the teachers and parents of $1^{\text {st }}$ grade students in primary schools, the parents and teachers of the fifth grade students in middle schools) and returned to Adiyaman Provincial Directorate of National Education. The quantitative study data were collected with the "Assessment Questionnaire for Draft-Based Branch Assignment Application," developed using the qualitative data between 01/06/2018 and 07/06/2018 through the announcement by Adiyaman Provincial Directorate of National Education in a WhatsApp group (school administrators, $1^{\text {st }}$ and $5^{\text {th }}$ grade teachers and parent were asked to complete the questionnaire) and the included Google form link.

Qualitative study data were analyzed with descriptive and content analysis. Before the data were analyzed, each interview form was coded for school administrators as A1, $\mathrm{A} 2, \ldots$, and for teachers as $\mathrm{T} 1, \mathrm{~T} 2, \ldots$, and for parents as P1, P2,... Then, each interview form was read and coded based on the substance of the form. The similar codes were combined under common themes. The coding process was conducted by the two authors. The themes determined by the two authors were compared and the inter-coder agreement rate was determined as $95 \%$. For the codes categorized under different themes, an agreement was reached between the coders based on consensus. In cases where a common code could not be determined, the themes were determined by obtaining the opinion of a third researcher. The frequencies for each theme were determined. In the presentation of the findings, certain participant expressions were included. In the analysis of the quantitative study data, descriptive statistical analysis and chi-square test were used.

In order to ensure the internal reliability of the study, the inter-coder agreement rate was calculated in qualitative data analysis and themes were determined based on the consensus of three researchers. All processes implemented in order to ensure the external reliability of the study were specified in detail and the raw data and analysis notes were recorded. In order to ensure the internal validity of the study, qualitative data and expert opinions were used when developing the questionnaire, and diversification strategy was adopted in the determination of data resources and the data were collected from individuals with different attributes. The findings are presented directly without author comments in order to ensure the external validity of the study and certain participant statements are quoted.

\section{Findings}

The views of the participants on the advantages of draft-based branch assignment application are presented in Figure 1. 


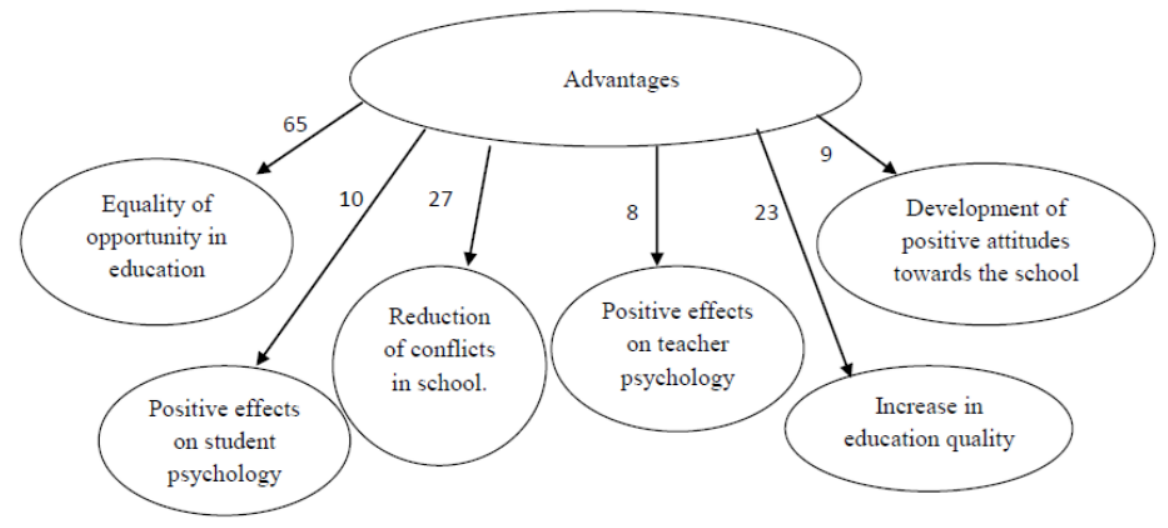

Figure 1. Participant views on the advantages of draft-based branch assignment application

As seen in Figure 1, the views of the participants on the advantages of draft-based branch assignment application included the following six themes: equality of opportunity in education, reduction of conflicts in school, increase in education quality, positive effects on student psychology, development of positive attitudes towards the school, and positive effects on teacher psychology. The most stressed theme was equality of opportunity in education, while the positive effects on teacher psychology theme was the least emphasized theme. One of the participating parents stated that the application had no advantages.

Twenty-nine teachers, 18 parents, and 18 school administrators, a total of 65 participants made statements on the theme of "equal opportunities in education." The views of the participants that reflected the facts that draft-based branch assignment application decreased the academic achievement differences between the classes, differences between class sizes, and the differences between the number of female and male students in a classroom; led to an equal and fair placement, preventing discrimination in the placement of students; prevented the inevitable classifications among teachers, classes and students at the beginning of the semester; prevented the teachers who were considered good during these classifications to work harder than the teachers who were considered to be less good and prevented higher expectations from the first group of teachers, contributing to equal workload on all teachers; the participant stressed the higher number of student enrollment to schools where the teachers that are considered to be good are employed, leading to significant differences between the schools in number of attending students and stated that the application reduced the differences in student body between different schools and forced the students to enroll at the neighborhood schools; they also stated that parents with teacher preferences had to pay significant fees to enroll their children in these schools and the application prevented this practice, and these views were grouped under the theme of "equal opportunities in education."

A total of 27 participants; 11 teachers, 4 parents and 12 school administrators, made statements on the theme of
"Reduction of conflict in school." They stated that before the draft-based branch assignment application, the parents argued with each other to enroll their children in the classes instructed by teacher who were considered as good teachers; pressured the school administration for this purpose; experienced conflicts with teachers who are considered to be bad; the teachers experienced problems with each other and with the administration about instructing the good/bad classes; the students also argued with each other on the same issue, and the views of the participants that the application reduced the conflicts between teachers, students, parents, teachers and parents, administrators and parents, administrators and teachers were grouped under the theme of "Reduction of conflicts in school."

Thirteen teachers, 5 parents and 5 school administrators, a total of 23 participants made statements on the theme of "Increase in the quality of education." The participant views that draft-based branch assignment application increased teacher performance due to the lack of classification between teachers and branches and similarity between the class achievement levels; the achievements of the students with low academic achievement levels were affected positively by the students with high academic achievement; increased the professional skills of teachers due to their interaction with students with different levels of achievement and behavioral characteristics; improved the awareness of the students on differences between their lives as a result of the interaction among the students with different socioeconomic, cultural, etc. backgrounds; increased the sense of responsibility of the parent since they no longer explained the failure of their children with the class level; leading to a class environment where the students could fulfill their potential due to the formation of classes with heterogeneous academic achievement levels were grouped under the theme of "Increase in the quality of education."

Four teachers, 3 parents, 3 school administrators, a total of 10 participants made statements about "Positive effects on student psychology," 2 teachers, 2 parents, 5 school administrators, a total of 9 participants made statements 
about "Development of positive attitudes towards the school," 4 teachers, 1 parent, and 3 school administrators, a total of 8 individuals made statements about "Positive effects on teacher psychology" themes. The views of the participants that draft-based branch assignment system prevented the students' presumption that they were unsuccessful; increased the student morale, self-confidence and motivation were grouped under the theme of "Positive effects on student psychology". The views of the participants that draft-based branch assignment system improved the assumption by the parents, teachers and students that all branches were good and positive attitudes towards the school such as confidence and belongingness were grouped under the theme of "Development of positive attitudes towards the school". Also, as a result of elimination of good-bad distinction between teachers and the disadvantage of providing education in a class of students with low academic achievement, teachers' morale and motivation were developed and a confident study environment was sustained, which were grouped under "Positive effects on teacher psychology" theme.

Sample participant statements on the advantages of the draft-based branch assignment application are presented below:

The determination of the branches by draft made a positive contribution to labor peace, because the students were distributed equally among all teachers and the students were mixed in each class. Equality of opportunity in education was achieved. Good classroom-bad classroom perceptions among the students, and the concept of good teacher-bad teacher perception among the teachers disappeared. $(A 1 / M / P)$
Good classroom-bad classroom division disappeared. The rumor about the branches among the parents was prevented. The application is a very good application. $(P 4 / F / M)$.

It allows the students of all levels to study in the same classroom environment. Since education is a process of interaction, different economic, social and cultural values are shared. There is no unnecessary competition between the classes and teachers. The achievement expectations from the teacher and the classroom become moderate. Equality of opportunity in education is achieved (T7/M/P).

The views of the participants on the disadvantages of draft-based branch assignment application are presented in Figure 2.

As seen in Figure 2, the participant views on the disadvantages of draft-based branch determination application were grouped under five themes: "Educational problems," "Inability of the parents to select the teacher," "Possibility of conflicts in schools," "Increase in number of school transfers," "Lack of differentiation between hard-working and other teachers." While the theme of "Educational problems" was emphasized most frequently, the theme of "Lack of differentiation between hard-working and other teachers" was emphasized the least. However, 6 out of 72 participants (4 parents, 1 school administrator, 1 teacher) did not express any views on the disadvantages of the application and 8 teachers, 9 parents and 8 school administrators, making totally 25 participants, stated that there were no disadvantages of the application. 31 participants expressed views on the disadvantages of the application.

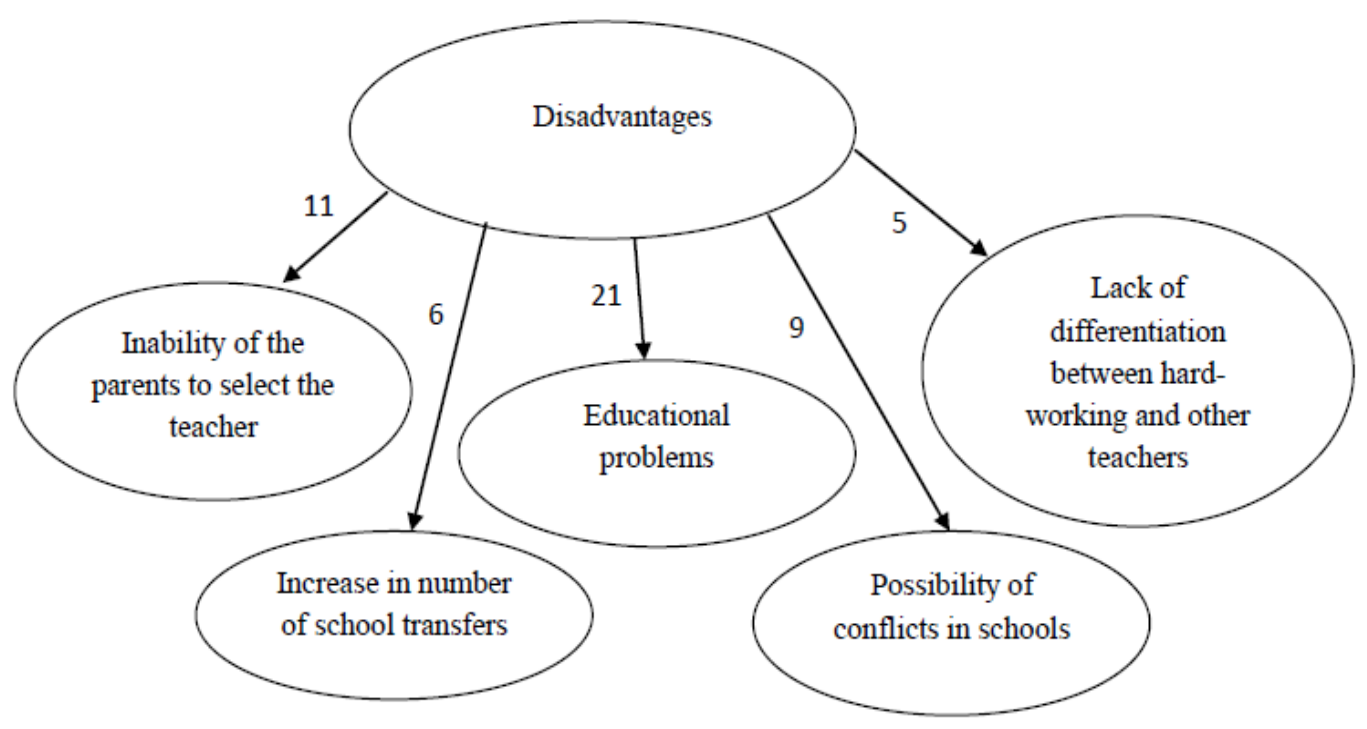

Figure 2. Participant views on the disadvantages of draft-based branch assignment application 
Twelve teachers, 6 parents and 3 school administrators, a total of 21 participants made statements about the theme of "Educational problems." The participant views that draft based branch assignment application led to the possibility of the selection of students with similar academic achievements in one classroom and the fact that students with special education needs and with low level of academic achievement and behavioral problems could end up in the same classroom could lead to educational problems and heterogeneous classes could prevent synergy in education, the teacher could experience confusion on determination of the instruction level due to different student achievement levels and the transferred students could experience problems in their new school were grouped under the theme of "Educational problems."

A total of 11 participants; 6 teachers, 2 parents and 3 school administrators made statements about the theme "Inability of the parents to select the teacher." Participants argued that individuals should have the right to select the teacher of their children by asserting that they have the right to choose, for example, their physician, the quality of the primary school teacher would affect the future education of the student, certain students preferred female teachers, while others preferred male teachers, etc. and these statements of the participants were grouped under the theme of "Inability of the parents to select the teacher."

A total of 9 participants; 3 teachers and 6 school administrators made statements about the theme of "Possibility of conflicts in schools." The views of the participants that the lack of teacher choice would lead to the placement of the students in classes of teachers undesired by the parents, which could lead to teacher-parent conflicts, which in turn could be reflected to the students and pressures on school administration to change the class of the students could increase were grouped under the theme of "Possibility of conflicts in schools."

A total of 6 participants; 1 teacher and 5 school administrators made statements about the theme of "Increase in number of school transfers." The statements of the participants that draft-based branch assignment application led to the transfer of students to other schools, especially to private schools due to reasons such as inability of the parents to select teachers and placement of "Increase in number of school transfers."

A total of 5 participants; 1 teacher and 4 school administrators made statements about the theme of "Lack of differentiation between hard-working and other teachers." Their statements that there was a differentiation between the hard-working and other teachers before the draft-based branch assignment application since there was high demand for high-performance teachers, however the application removed the distinction between hard-working and other teachers were grouped under the theme of "Lack of differentiation between hard-working and other teachers."

Sample participant statements on the disadvantages of the draft-based branch assignment application are presented below:

If one can choose the physician in healthcare, it should be possible to choose the teacher who guides the lives of our children who are our future. The draft method is nothing but trouble. Those who does not like the teacher take their children to private schools or implement other sanctions. Teacher selection is inevitable. $(A 2 / M / P)$.

In our country, students and parents have the right to choose teachers if they have the freedom to choose physicians. In classrooms, we should have the right to choose teachers to distinguish between the good and the bad, and to choose the children who will be the future of our country. We should separate the good and the bad and the hard-working and non-working. $(P 13 / M / P)$.

The disadvantage, various problems could be experienced when they are assigned to classrooms where there are students with low achievement level or behavioral problems (T20/M/M).

The descriptive statistics related to the items about the assessment of draft-based branch assignment application and participant perceptions on these items are presented in Table 1. 
Tablo 1. The descriptive statistics on participant perceptions about the assessment of draft-based branch assignment application

\begin{tabular}{|c|c|c|c|c|c|c|c|c|}
\hline \multirow[t]{2}{*}{ Questionnaire items } & \multicolumn{2}{|c|}{$\begin{array}{l}\text { Administrator } \\
(\mathrm{n}=123)\end{array}$} & \multicolumn{2}{|c|}{$\begin{array}{l}\text { Teacher } \\
(\mathrm{n}=577)\end{array}$} & \multicolumn{2}{|c|}{$\begin{array}{c}\text { Parent } \\
(\mathrm{n}=428)\end{array}$} & \multicolumn{2}{|c|}{$\begin{array}{c}\text { Total } \\
(\mathrm{n}=1128)\end{array}$} \\
\hline & $\bar{x}$ & SS & $\bar{x}$ & SS & $\bar{x}$ & SS & $\bar{x}$ & SS \\
\hline $\begin{array}{l}\text { 1. It decreases the academic achievement difference } \\
\text { between the classes. }\end{array}$ & 3.52 & 1.44 & 3.75 & 1.32 & 3.47 & 1.46 & 3.62 & 1.39 \\
\hline 2. It decreases the difference between class size. & 3.67 & 1.51 & 3.85 & 1.34 & 3.62 & 1.43 & 3.74 & 1.40 \\
\hline $\begin{array}{l}\text { 3. It prevents discriminative assignment of students } \\
\text { to classes. }\end{array}$ & $3.94 *$ & 1.35 & $4.04 *$ & 1.29 & $3.79 *$ & 1.48 & $3.93 *$ & 1.37 \\
\hline $\begin{array}{l}\text { 4. It prevents prejudicial class assignment (good-bad } \\
\text { student, good-bad class, good-bad teacher) at } \\
\text { schools. }\end{array}$ & 3.78 & 1.45 & 4.00 & 1.29 & 3.75 & 1.50 & 3.88 & 1.39 \\
\hline 5. It contributes to similar teacher performances. & 3.42 & 1.53 & 3.67 & 1.38 & 3.54 & 1.52 & 3.59 & 1.45 \\
\hline $\begin{array}{l}\text { 6. It reduces illegal enrollment fees requested during } \\
\text { registration at schools. }\end{array}$ & 3.72 & 1.42 & 3.84 & 1.34 & 3.62 & 1.56 & 3.74 & 1.44 \\
\hline $\begin{array}{l}\text { 7. It decreases conflicts between school stakeholders } \\
\text { induced by prejudicial classification (good-bad } \\
\text { student, good-bad class, good-bad teacher). }\end{array}$ & 3.65 & 1.51 & 3.88 & 1.29 & 3.62 & 1.46 & 3.75 & 1.38 \\
\hline $\begin{array}{l}\text { 8. It reduces "I am a failure" prejudice of the } \\
\text { students. }\end{array}$ & 3.20 & 1.59 & 3.53 & 1.42 & 3.29 & 1.52 & 3.40 & 1.48 \\
\hline $\begin{array}{l}\text { 9. It contributes to a homogenous classroom } \\
\text { environment where the students could fulfill their } \\
\text { potential. }\end{array}$ & 3.62 & 1.42 & 3.73 & 1.35 & 3.48 & 1.45 & 3.62 & 1.40 \\
\hline 10. It improves student morale. & 3.23 & 1.54 & 3.47 & 1.42 & 3.29 & 1.51 & 3.38 & 1.47 \\
\hline 11 It improves student self-confidence. & 3.21 & 1.53 & 3.49 & 1.42 & 3.35 & 1.51 & 3.41 & 1.47 \\
\hline 12. It improves student motivation. & 3.15 & 1.51 & 3.44 & 1.40 & 3.35 & 1.52 & 3.37 & 1.46 \\
\hline $\begin{array}{l}\text { 13. It improves academic achievements of the } \\
\text { students. }\end{array}$ & 3.09 & 1.49 & 3.33 & 1.40 & 3.25 & 1.50 & 3.27 & 1.45 \\
\hline 14. It improves teacher motivation. & 3.44 & 1.50 & 3.60 & 1.41 & 3.43 & 1.48 & 3.52 & 1.45 \\
\hline 15. It improves teacher morale. & 3.41 & 1.52 & 3.67 & 1.40 & 3.43 & 1.48 & 3.55 & 1.44 \\
\hline 16. It improves teacher performance. & 3.26 & 1.54 & 3.55 & 1.41 & 3.32 & 1.53 & 3.43 & 1.47 \\
\hline $\begin{array}{l}\text { 17. It enables teachers to interact with students with } \\
\text { different attributes and develops their occupational } \\
\text { skills. }\end{array}$ & 3.44 & 1.48 & 3.64 & 1.36 & 3.44 & 1.44 & 3.54 & 1.41 \\
\hline $\begin{array}{l}\text { 18. It may lead to a heterogeneous classroom } \\
\text { environment that could contribute to positive } \\
\text { academic influence of students on each other. }\end{array}$ & 3.43 & 1.49 & 3.62 & 1.32 & 3.43 & 1.38 & 3.52 & 1.37 \\
\hline $\begin{array}{l}\text { 19. It improves the sense of responsibility of parents } \\
\text { towards the education of their children. }\end{array}$ & 3.00 & 1.53 & 3.20 & 1.43 & 3.33 & 1.50 & 3.23 & 1.47 \\
\hline $\begin{array}{l}\text { 20. It contributes to the interaction between students } \\
\text { with different attributes. }\end{array}$ & 3.48 & 1.47 & 3.70 & 1.34 & 3.54 & 1.40 & 3.62 & 1.38 \\
\hline $\begin{array}{l}\text { 21. It helps school stakeholders to develop positive } \\
\text { attitudes towards the school. }\end{array}$ & 3.36 & 1.50 & 3.56 & 1.31 & 3.40 & 1.42 & 3.48 & 1.38 \\
\hline $\begin{array}{l}\text { 22. This is an application that I do not approve since I } \\
\text { think parents have the right to choose the teacher. }\end{array}$ & 2.81 & 1.55 & 2.57 & 1.57 & 2.84 & 1.68 & 2.70 & 1.62 \\
\hline 23. It encourages parents to prefer private schools. & 2.54 & 1.43 & 2.62 & 1.42 & 2.88 & 1.52 & 2.71 & 1.46 \\
\hline $\begin{array}{l}\text { 24. It has negative effect on the academic } \\
\text { achievement of successful students in a } \\
\text { heterogeneous classroom environment. }\end{array}$ & 2.29 & 1.41 & 2.40 & 1.36 & 2.67 & 1.48 & 2.49 & 1.42 \\
\hline $\begin{array}{l}\text { 25.It leads to educational problems with respect to } \\
\text { academic achievement in a heterogeneous classroom } \\
\text { environment. }\end{array}$ & 2.22 & 1.35 & 2.32 & 1.33 & 2.61 & 1.46 & 2.42 & 1.39 \\
\hline $\begin{array}{l}\text { 26. It may lead to placement of students with similar } \\
\text { academic achievement levels in the same classroom. }\end{array}$ & 2.15 & 1.31 & 2.35 & 1.30 & 2.59 & 1.44 & 2.42 & 1.36 \\
\hline $\begin{array}{l}\text { 27. It may lead to placement of students with similar } \\
\text { behavioral problems in the same classroom. }\end{array}$ & $2.07 *$ & 1.23 & $2.31 *$ & 1.29 & $2.50^{*}$ & 1.40 & $2.36^{*}$ & 1.33 \\
\hline $\begin{array}{l}\text { 28. It leads to removal of the differentiation between } \\
\text { hard-working and other teachers. }\end{array}$ & 2.63 & 1.55 & 2.67 & 1.54 & 3.03 & 1.54 & 2.80 & 1.55 \\
\hline
\end{tabular}


Based on the data presented in Table 1, the item that participants most frequently agreed on about the assessment of draft-based branch assignment application was "It prevents discriminative assignment of students to classes" ( $\bar{X}=$ Administrator: 3.94; Teacher: 4.04; Parent: 3.79; Total: 3.63), while the item that participants least frequently agreed on was "It may lead to placement of students with similar behavioral problems in the same classroom" ( $\bar{X}=$ Administrator: 2.07; Teacher: 2.31; Parent: 2.50; Total: 2.36). Furthermore, based on the arithmetic mean of the items presented in Table 1, more participants agreed on the positive items about the assessment of draft-based branch assignment application when compared to the negative items.

In order to determine whether there was a significant difference between the participant views on the continuation of draft based branch assignment based on the stakeholder variable, chi-square test was conducted, and the results are presented in Table 2 .

As seen in Table 2,70.7\% of the participants gave positive responses and $29.3 \%$ gave negative responses for the continuation of draft-based branch determination application. The ratio of the administrators who answered "Yes" to the continuation of draft-based branch determination application was $68.3 \%$, the same ratio was $75.6 \%$ for the teachers and the same ratio was $64.7 \%$ for the parents. Based on the stakeholder variable, this difference between the views on the continuation of draft-based branch determination application was significant $\left[x^{2} \quad(\mathrm{sd}=2, \mathrm{n}=1128)=14.308, \mathrm{p}<.05\right]$. In other words, there was a significant correlation between the stakeholder variable and the views on the continuation of draft-based branch determination application. It was observed that the ratio of teachers who replied "Yes" to the continuation of draft-based branch determination application was higher than that of the parents and administrators. It was also determined that the ratio of administrators who replied "Yes" to the continuation of draft-based branch determination application was higher than that of the parents.

In order to determine whether there was a significant difference between the participant views on the continuation of draft based branch assignment based on the school type variable, chi-square test was conducted, and the results are presented in Table 3.

Table 2. Participant views on the continuation of draft based branch assignment based on the stakeholder variable

\begin{tabular}{|c|c|c|c|c|c|c|c|}
\hline \multirow{2}{*}{$\begin{array}{l}\text { Stakeholder } \\
\text { variable }\end{array}$} & \multicolumn{4}{|c|}{ Views on the continuation of draft based branch assignment } & \multirow{2}{*}{$\begin{array}{c}\text { Pearson } \\
\text { Chi-Square }\left(X^{2}\right)\end{array}$} & \multirow[t]{2}{*}{ sd } & \multirow[t]{2}{*}{$\mathrm{p}$} \\
\hline & & Yes & No & Total & & & \\
\hline \multirow{2}{*}{ Administrator } & $\mathrm{N}$ & 84 & 39 & 123 & \multirow{8}{*}{14.308} & \multirow{8}{*}{2} & \multirow{8}{*}{$.001 *$} \\
\hline & $\%$ & $68.3 \%$ & $31.7 \%$ & $100.0 \%$ & & & \\
\hline \multirow{2}{*}{ Teacher } & $\mathrm{N}$ & 436 & 141 & 577 & & & \\
\hline & $\%$ & $75.6 \%$ & $24.4 \%$ & $100.0 \%$ & & & \\
\hline \multirow{2}{*}{ Parent } & $\mathrm{N}$ & 277 & 151 & 428 & & & \\
\hline & $\%$ & $64.7 \%$ & $35.3 \%$ & $100.0 \%$ & & & \\
\hline \multirow{2}{*}{ Total } & $\mathrm{N}$ & 797 & 331 & 1128 & & & \\
\hline & $\%$ & $70.7 \%$ & $29.3 \%$ & $100.0 \%$ & & & \\
\hline
\end{tabular}

Table 3. Participant views on the continuation of draft based branch assignment based on the school type variable

\begin{tabular}{|c|c|c|c|c|c|c|c|}
\hline \multirow{2}{*}{ School type } & \multicolumn{4}{|c|}{ Views on the continuation of draft based branch assignment } & \multirow[t]{2}{*}{$\begin{array}{c}\text { Continuity } \\
\text { Correction }^{\mathrm{b}}\left(X^{2}\right) \\
\end{array}$} & \multirow[t]{2}{*}{ sd } & \multirow[t]{2}{*}{$\mathrm{p}$} \\
\hline & & Yes & No & Total & & & \\
\hline \multirow{2}{*}{ Primary School } & $\mathrm{N}$ & 439 & 195 & 634 & \multirow{6}{*}{1.243} & \multirow{6}{*}{1} & \multirow{6}{*}{,265 } \\
\hline & $\%$ & $69.2 \%$ & $30.8 \%$ & $100.0 \%$ & & & \\
\hline \multirow{2}{*}{ Middle School } & $\mathrm{N}$ & 358 & 136 & 494 & & & \\
\hline & $\%$ & $72.5 \%$ & $27.5 \%$ & $100.0 \%$ & & & \\
\hline \multirow{2}{*}{ Total } & $\mathrm{N}$ & 797 & 331 & 1128 & & & \\
\hline & $\%$ & $70.7 \%$ & $29.3 \%$ & $100.0 \%$ & & & \\
\hline
\end{tabular}


Based on the Table 3, there was no significant correlation between school type variable and the views on the continuation of draft-based branch determination application $\left[x^{2}(\mathrm{sd}=1, \mathrm{n}=1128)=1.243, \mathrm{p}>.05\right]$. Thus, it can be suggested that the ratio of "Yes" responses on the continuation of draft-based branch determination application in primary and middle schools were similar.

\section{Discussion}

In the qualitative section of the study, the "Equal opportunity in education" theme was the most frequently emphasized theme about the advantages of draft based branch assignment application. The participants stated that draft-based branch assignment practice decreased the differences in academic achievement, class size and gender among the classes; led to an equal and fair placement, preventing discrimination in the placement of students; inevitable classifications among teachers, classes and students at the beginning of the semester. Furthermore, the practice prevented the teachers who were considered good during these classifications to work harder than the teachers who were considered to be less good and prevented higher expectations from the first group of teachers, contributing to equal workload on all teachers. The participants stressed the higher number of student enrollment to schools where the teachers that are considered to be good are employed, leading to significant differences between the schools in number of attending students and stated that the application reduced the differences in student body between different schools and forced the students to enroll at the neighborhood schools. They also stated that parents with teacher preferences had to pay significant fees to enroll their children in these schools and the application prevented this practice. In the quantitative section of the study, it was determined that a high number of participants agreed that draft based branch assignment application "It prevents discriminative assignment of students to classes," while they mostly agreed on the statements "It decreases the academic achievement difference between the classes," "It decreases the difference between class size," "It prevents prejudicial class assignment (good-bad student, good-bad class, good-bad teacher) at schools," "It contributes to similar teacher performances," "It reduces illegal enrollment fees requested during registration at schools." Thus, it can be suggested that the qualitative findings were consistent with the quantitative findings and the qualitative results can be generalized to the larger sample group. Furthermore, these findings may indicate that the application achieved its goal of contributing to the successful operation of residence-based enrollment system since it prevents school selection in addition to prevention of teacher selection and formation of elite classes at schools. A similar application was implemented in Korea in 1969. In Korea, the entrance exam for middle schools was abolished and primary school graduates were placed in middle schools in their neighborhood with a draft. Domicile-based enrollment with draft was considered more equitable when compared to enrollment based on exam results which could be affected by socioeconomic factors. This application, which was also adopted by school stakeholders, eliminated elite middle schools, increased middle school access, and balanced the quality of schools. It was considered that this policy was behind the above-average academic achievement level in Korea among OECD nations and the below-average impact of socioeconomic factors on achievement and the differences in achievement between schools [4].

It was determined that the most frequently emphasized theme about the disadvantages of draft-based branch assignment application was "Educational problems" (21 out of 72 participants). The participants stated that draft based branch assignment application led to the possibility of the selection of students with similar academic achievements and behavior in one classroom and the fact that students with special education needs and with low level of academic achievement and behavioral problems could end up in the same classroom could lead to educational problems and heterogeneous classes could prevent synergy in education, the teacher could experience confusion on determination of the instruction level due to different student achievement levels and the transferred students could experience problems in their new school. In the quantitative section of the study, the least number of participants agreed on the statement that "It may lead to placement of students with similar behavioral problems in the same classroom," while only few participants agreed with the statements "It has negative effect on the academic achievement of successful students in a heterogeneous classroom environment," "It leads to educational problems with respect to academic achievement in a heterogeneous classroom environment," "It may lead to placement of students with similar academic achievement levels in the same classroom." Thus, it could be argued that the application has a low probability of leading negative outcomes. Furthermore, heterogeneous student groups should not be considered as a problem but an advantage. While heterogeneous student groups constitute the basis of collaborative learning, which is emphasized in modern education, it is based on the belief that students would share their ideas and study collaboratively, while conducting their tasks in the most effective manner [31]. In this learning method, heterogeneous groups were formed to ensure that individuals in these groups could learn by helping each other. Thus, students with different skills, development levels and educational backgrounds could eliminate artificial barriers by establishing relationships with each other. On the other hand, one of the main functions of education is to achieve homogeneous groups of students 
who are initially heterogeneous [32]. In other words, education aims to make the students with low academic achievement to achieve the academic achievement levels of students with high academic achievement in a group of students with different academic achievement levels. Furthermore, teachers were recommended to create homogenous groups in the classroom based on gender, academic achievement, skills and socioeconomic properties in educational processes and to establish a collaborative environment to promote development and learning [33].

In the study, it was determined that there was no significant correlation between the views on the continuation of draft based branch determination application based on the school type variable. However, based on the stakeholder variable, there was a significant correlation between the views on the continuation of draft based branch determination application, and it was concluded that teachers preferred the continuation of draft based branch determination application more when compared to school administrators and parents, and school administrators preferred the continuation of draft based branch determination application more when compared to parents. This is certain parents considered that they have the right to choose the teachers who would instruct their children and that they did not consider it democratic to take away this right [19].

\section{Conclusions}

In the study, it was determined that more than half of the participants replied "Yes" to the continuation of draft based branch determination application and based on this findings, it could be suggested that the participants preferred the continuation of the draft based branch determination application. Thus, it could be stated that the positive results of the application were more than its negative results, which is confirmed by both the qualitative and quantitative study findings. In fact, 6 out of 72 participants in the qualitative section of the study (4 parents, 1 school administrators, 1 teacher) did not express any view on the disadvantages of the application. Also, 8 teachers, 9 parents, and 8 school administrators, making totally 25 participants, declared that the application has no negative point. However, only 31 participants voiced views on disadvantages of the application. On the other hand, 71 participants expressed views on advantages of the application. In the quantitative section of the study, a higher number of participants agreed with the positive items on draft based branch determination application when compared to the negative items. Thus, it can be suggested that qualitative and quantitative study findings were similar and the qualitative findings could be generalized to a larger sample group.

The following recommendations are presented based on study findings:
- The application provides individuals equal chance and opportunity. However, one of the negative aspects of this application is the probability that students with similar behavioral problems could be placed in the same class. In order to reduce this possibility, students with similar behavioral problems could be distributed to classes based on their counseling files. Furthermore, these students could be transferred to other classes after the implementation of draft based assignment system based on the counselor opinion.

- $\quad$ Based on the present study findings, positive results would be obtained by adopting the draft-based branch determination application in preschool and secondary education institutions.

- It could be suggested that the application provides equal opportunities in education. Equality of opportunity in education is a primary issue for the states. Thus, applications that aim to achieve equal opportunities in education could be conducted and the results could be analyzed to assess their effectiveness.

\section{REFERENCES}

[1] Duryea, S., Galiani, S. Ñopo, H. \& Piras, C. The educational gender gap in Latin America and the Caribbean. Working paper // InterAmerican Development Bank, Research Department, No. 600, Inter-American Development Bank, Research Dep., Washington, DC, 2007, Online available from http://hdl.handle.net/10419/51439

[2] Sarier, Y. An evaluation of equal opportunities in education in the light of high school entrance exams (OKS-SBS) and PISA results. Journal of Kirsehir Education Faculty, Vol.11, No.3, 107-129, 2010.

[3] Kandemir, O. \& Kaya, F. The impact influence of income distribution on equality of opportunities in higher education: Private university reality in Turkey. Kastamonu Education Journal, Vol.18, No.2, 557-566, 2010.

[4] Polat, S. Türkiye'de eğitim politikalarının firsat eşitsizliği üzerindeki etkileri. DPT-Uzmanlık tezleri. Sosyal Sektörler ve Koordinasyon Genel Müdürlüğü, Ankara, 2009, http://www3.kalkinma.gov.tr/PortalDesign/PortalControls/ WebIcerikGosterim.aspx?Enc=83D5A6FF03C7B4FC36D3 40292 4704B39

[5] Buluç. B. İlköğretim ikinci kademe okullarda eğitimde fursat ve imkân eşitliği. Kuram ve Uygulamada Eğitim Yönetimi Dergisi, Vol.3, No.1, 11-21, 1997.

[6] Gamoran, A. American schooling and educational inequality: A forecast for the 21st century. Sociology of Education Extra Issue, Vol.74, 135-153, 2001.

[7] Gürel, N. \& Kartal, S. Examining access to education in Turkey according to some variables. Elementary Education Online, Vol.14, No.2, 593-608, 2015, Online available from http://dx.doi.org/10.17051/io. 2015.60429 
[8] Huggins, A., \& Randell, S. K. Gender equality in education in Rwanda: What is happening to our girls. In South African Association of Women Graduates Conference. South Africa: Cape Town, 2007, Online available from http://citeseerx.ist.psu.edu/viewdoc/download?doi=10.1.1.5 $77.4103 \&$ rep $=$ rep $1 \&$ type $=$ pdf

[9] Lee, M. H. The one-child policy and gender equality in education in China: Evidence from household data. Journal of family and economic issues, Vol.33, No.1, 41-52, 2012, Doi: 10.1007/s10834-011-9277-9.

[10] Subrahmanian, R. Gender equality in education: Definitions and measurements. International Journal of Educational Development, Vol.25, 395-407, 2005.

[11] Unterhalter, E. Global inequality, capabilities, social justice: The millennium development goal for gender equality in education. International Journal of Educational Development, Vol.25, 111-122, 2005.

[12] Yaşar, M. M. Equal opportunity in education from socioeconomic perspective: The case of Giresun, Unpublished master thesis, Giresun University, Institute of Social Sciences, Giresun, 2014.

[13] Field, S., Kuczera, M. V.\& Pont, B. No more failures: Ten steps to equity in education. Education and Training Policy. OECD, 2007. Online available from https://www.oecd.org/ education/school/45179151.pdf

[14] Atlama, S. \& Özsoy, C. Educational gender gap: The comparative analyze of Turkey, International 7th Knowledge, Economy, Management Congress, 63-77, 2009.

[15] Sayllan, F. Toplumsal cinsiyet ve eğitim. Ankara: Dipnot Yayınları, 2012, http://www.antalyakadinmuzesi.or g/dosyalar/dosyalar/toplumsal_cinsiyet_ve_egitim.pdf

[16] Canöz, T. The analysis of educational policies in Turkey in terms of equality of opportunity in education between 2003-2013. Unpublshed master's thesis, Fatih University, Institute of Social Sciences, 2014

[17] Mercik, V. The relationship between the equality of opportunity in education, general social success and justice: The comparison of Finland and Turkey experiences within the scope of PISA Project. Unpublished master's thesis, Balikesir University, Institute of Social Sciences, Balikesir, 2015.

[18] Tansel, A. Inequality of opportunities of educational achievement in Turkey over time. IZA Discussion Papers, No. 9005, Institute for the Study of Labor (IZA), Bonn, 2015, Online available from https://papers.ssrn.com/sol3/ papers.cfm?abstract_id $=2598161$

[19] Sincar, M. \& Özbek, M. School administrators' opinions on the enrollment of students through the address-based population register system. Journal of Education and Humanities : Theory and Practice, Vol.2, No.3, 29-52, 2011.

[20] Hallinan, M. T. Equality in education. In D. L. Levinson, P. W. Cookson \& A. R. Sadovnik (Eds.) Education and Sociology. (pp. 241-246). London and Newyork: Routledge Taylor \& Francis Group, 2013.

[21] Darling-Hammond, L. Teacher quality and student achievement. Education policy analysis archives, Vol.8, No.1, 2000, Online available from https://epaa.asu.edu/ojs/ article/ view/392

[22] Hattie, J.A.C. Teachers make a difference: What is the research evidence? Paper presented at the Building Teacher Quality: What does the research tell us ACER Research Conference, Melbourne, Australia, 2003, Online available from

http://research.acer.edu.au/researchconference_2003/4/

[23] Rockoff, J. E. The impact of individual teachers on student achievement: Evidence from panel data. American Economic Review, Vol.94, No.2, 247-252, 2004.

[24] Coleman, J.S., Campbell, E.Q., Hobson, C.J., McPartland, J., Mood, A.M., Weinfeld, F.D., \& York, R.L. Equality of educational opportunity. Washington, DC: U.S. Government Printing Office, 1966.

[25] Jackson, G. \& Cosca, C. The inequality of educational opportunity in the southwest: An observational study of ethnically mixed classrooms. American Educational Research Journal, Vol.11, No.3, 219-229, 1974.

[26] Büyüköztürk, Ş., Kılıç Çakmak, E., Akgün, Ö. E., Karadeniz, Ş. \& Demirel, F. Bilimsel araştırma yöntemleri. Ankara: Pegem Akademi, 2016.

[27] Yıldırım, A. \& Şimşek, H. Sosyal bilimlerde nitel araştırma yöntemleri. Ankara: Seçkin Yayıncılık, 2011.

[28] Vural, R. A. \& Cenkseven, F. Case studies in educational research: Definition, Types, Stages and Reporting of Case Study Research, Journal of Burdur Education Faculty, Vol.6, No.10, 126-139, 2005.

[29] Ferreira, F. H. G. \& Gignoux, J. Eğitimde firsat eşitsizliği: Türkiye örneği. TC Cumhuriyeti DPT ve Dünya Bankası Refah ve Sosyal Politika Analitik Çalıșma Programı. Çalışma Raporu, 4, 2010. Online available from http://abdigm.meb.gov.tr/projeler/ois/egitim/006.pdf adresinden edinildi.

[30] Creswell, J. W. \& Plano Clark, V. L. Karma yöntem desen seçimi. (A. Delice, Çev.) Y. Dede \& S. B. Demir (Çev. Eds.). Karma yöntem araştırmaları: Tasarımı ve yürütülmesi kitabı içinde. (s.61-116). Ankara: Anı Yayınc1lık, 2015.

[31] Zakaria, E. \& Iksan, Z. Promoting cooperative learning in science and mathematics education: A Malaysian perspective. Eurasia Journal of Mathematics, Science \& Technology Education, Vol.3, No.1, 35-39, 2007.

[32] Demirel, Ö. Eğitimde nitelik geliştirmede işbirliğine dayalı öğrenme ile tam öğrenmenin yeri ve önemi. Eğitim ve Bilim, Vol.15, No.82, 1991.

[33] Korkmaz, İ. Sosyal öğrenme kuramı. B. Yeşilyaprak (Ed.) Gelişim ve öğrenme psikolojisi kitabı içinde. Ankara: Pegem A Yayıncilik, 2002.

[34] Buis, M. L. Not all transitions are equal: The relationship between inequality of educational opportunities and inequality of educational outcomes, 2008. Online available from http://www.maartenbuis.nl/wp/distmare.pdf

[35] Tezcan, M. Eğitim sosyolojisi. Ankara Üniversitesi Eğitim Bilimleri Fakültesi Yayınları. 150, 1985. 
[36] Türkiye İstatistik Kurumu. Cinsiyet ve okuryazarlık durumuna göre nüfus, 2019. Online available from http://tuik.gov.tr/PreTablo.do?alt_id=1018

[37] Dünya Bankası. Türkiye'de temel eğitimde kalite ve eşitliğin geliştirilmesi: Zorluklar ve seçenekler. . Washington: The World Bank, 2011. Online available from https://abdigm.m eb.gov.tr/projeler/ois/egitim/007.pdf

[38] Eğitimde Fatih projesi, 2019. Online available from http://fatihprojesi.meb.gov.tr/ 